\title{
New tetracyclic heteroaromatic compounds based on dehydroamino acids: photophysical and electrochemical studies of interaction with DNA
}

\author{
Maria-João R.P. Queiroz ${ }^{\text {a, } *}$, Elisabete M.S. Castanheira ${ }^{\text {b }}$, M. Solange D. Carvalho ${ }^{\text {a }}$, \\ Ana S. Abreu ${ }^{\mathrm{a}, \mathrm{b}}$, Paula M.T. Ferreira ${ }^{\mathrm{a}}$, Hakan Karadeniz ${ }^{\mathrm{c}}$, Arzum Erdem ${ }^{\mathrm{c}, *}$ \\ a Centro de Química, Universidade do Minho, Campus de Gualtar, 4710-057 Braga, Portugal \\ ${ }^{\text {b } C e n t r o ~ d e ~ F i ́ s i c a, ~ U n i v e r s i d a d e ~ d o ~ M i n h o, ~ C a m p u s ~ d e ~ G u a l t a r, ~ 4710-057 ~ B r a g a, ~ P o r t u g a l ~}$ \\ c Analytical Chemistry Department, Faculty of Pharmacy, Ege University, 35100 Bornova, Izmir, Turkey
}

Received 25 July 2007; received in revised form 19 October 2007; accepted 25 October 2007

\begin{abstract}
A benzothienoindole (BTIN) and a benzofuroindole (BFIN) were synthesized in high yields, as potential new DNA target compounds, using a metal-assisted intramolecular $\mathrm{C}-\mathrm{N}$ cyclization of the methyl esters of $N$-(tert-butoxycarbonyl)- $\beta$, $\beta$-bis(dibenzothien-4-yl or dibenzofur-4-yl)dehydroalanines. The latter were obtained by a bis-Suzuki coupling of a $\beta, \beta$-dibromodehydroalanine with the corresponding heteroarylboronic acids. The absorption and fluorescence properties of the new tetracyclic compounds were studied in different solvents and in the presence of salmon sperm DNA. The results in several solvents show that either BTIN or BFIN can be used as fluorescence solvent sensitive probes. Spectroscopic studies of their interaction with dsDNA allowed to determine binding constant $\left(K_{\mathrm{i}}\right)$ values and binding site sizes $(n)$. Fluorescence quenching experiments using iodide ion showed that intercalation is the preferred mode of binding to DNA. From the results obtained, BTIN is the more intercalative compound and has a higher affinity to DNA. The interaction of BTIN with DNA was also studied electrochemically, by using differential pulse voltammetry (DPV) in connection with disposable pencil graphite electrode (PGE). After the interaction of BTIN with DNA, the oxidation signals of BTIN and adenine strongly decreased. The latter result was attributed to the binding of BTIN to DNA and the former points to a possible damage of the oxidizable groups of BTIN after intercalation into DNA. The results of spectroscopic and electrochemical studies of BTIN interaction with DNA are in good agreement.
\end{abstract}

(C) 2007 Elsevier Ltd. All rights reserved.

Keywords: Heteroaromatic tetracyclic compounds; Dehydroamino acids; Fluorescence; Electrochemistry; DNA interaction

\section{Introduction}

The interaction of DNA with small molecules is an important fundamental issue in life sciences. ${ }^{1}$ The investigation based on DNA interactions has a key importance in order to understand the mechanisms of action of some antitumour and antiviral drugs and to design new DNA-targeted drugs. ${ }^{2}$ A recent active area of research is to explore the nature and dynamics of binding small molecules to biomacromolecules. $^{3,4}$ There are three modes of binding of molecules to

* Corresponding authors. Tel.: +351 253604378; fax: +351 253604382 (M.-J.R.P.Q); tel.: +90 232388 0110x5131; fax: +90 2323885258 (A.E.).

E-mail addresses: mjrpq@quimica.uminho.pt (M.-J.R.P. Queiroz), arzum. erdem@ege.edu.tr (A. Erdem).
DNA: intercalation into the base pairs, in the grooves ('major' or 'minor') and outside the helix by electrostatic interactions. Small molecules are stabilized on groove binding and intercalation with DNA through a series of associative interactions such as $\pi$-stacking, hydrogen bonding, attractive van der Waals and hydrophobic interaction. ${ }^{2}$

The interactions of some specific small molecules, such as some anticancer agents, with DNA have been studied using a variety of techniques. ${ }^{5-8}$ Absorption and fluorescence emission spectroscopies are important tools for monitoring DNA-binding processes. The interaction of fluorescent planar polycyclic molecules with DNA can be conveniently observed by these methods, because their absorption and emission properties change significantly on complex formation. ${ }^{9}$ Fluorescence quenching experiments using external quenchers 
are also very useful to establish the DNA-binding modes, ${ }^{10-12}$ since intercalated chromophores are less accessible to anionic quenchers due to electrostatic repulsion with negatively charged DNA. ${ }^{11}$

Recently, there is a growing interest in the design of biosensors that exploit interactions between surface-confined DNA and target drugs for their rapid screening. ${ }^{13-25}$ Electrochemical DNA biosensors (genosensors) play an important role for pharmaceutical, clinical, environmental and forensic applications, ${ }^{13-18}$ since electrochemistry provides rapid, simple and low-cost point-of-care detection of specific nucleic acid sequences, and also the interaction between ligands and nucleic acids.

For some years till now, some of us have been interested in the synthesis of heteroaromatic systems using a metal-assisted $\mathrm{C}-\mathrm{N}$ intramolecular cyclization of $\beta, \beta$-diaryl or diheteroaryldehydroamino acids obtained by Suzuki coupling. ${ }^{26,27}$ Here, we present the synthesis of new fluorescent tetracyclic compounds, a benzothienoindole (BTIN) and a benzofuroindole (BFIN) using the same methodology. The photophysical properties (absorption and fluorescence) of these two compounds in several solvents and in the presence of dsDNA were studied. Electrochemical studies of BTIN interaction with dsDNA were also carried out.

\section{Results and discussion}

\subsection{Synthesis}

New tetracyclic compounds, a benzothienoindole (BTIN) and a benzofuroindole (BFIN), were obtained in high yields by a $\mathrm{C}-\mathrm{N}$ metal-assisted intramolecular cyclization, developed by us, ${ }^{26,27}$ of the also new bis-Suzuki coupling products 1 and 2 . The latter were obtained from a $\beta, \beta$-dibromodehydroalanine derivative, ${ }^{26 a}$ and dibenzothien-4-yl and dibenzofur-4-yl boronic acids, in good yields, using Suzuki coupling conditions $^{26 \mathrm{c}}$ (Scheme 1).
The mechanism for the intramolecular cyclization proposed by us involves the formation of a palladacycle that after extrusion of $\operatorname{Pd}(0)$ gives the pyrrole ring, followed by cleavage of the Boc group. Copper acetate re-oxidizes $\operatorname{Pd}(0)$ to $\operatorname{Pd}(\mathrm{II})$, avoiding the use of a stoichiometric amount of $\mathrm{Pd}(\mathrm{OAc})_{2} \cdot{ }^{27}$

\subsection{Photophysical properties of BTIN and BFIN}

\subsubsection{In several solvents}

The absorption and fluorescence properties of BTIN and BFIN were studied in several solvents. The maximum absorption $\left(\lambda_{\mathrm{abs}}\right)$ and emission wavelengths $\left(\lambda_{\mathrm{em}}\right)$, molar extinction coefficients and fluorescence quantum yields of BTIN and BFIN are presented in Table 1. The fluorescence quantum yields were determined by the standard method, ${ }^{28}$ using 9,10-diphenylanthracene in ethanol as reference $\left(\Phi_{\mathrm{r}}=0.95\right) .^{29}$

The normalized fluorescence spectra of BTIN and BFIN are shown in Figures 1 and 2, respectively. Examples of absorption spectra are shown as inset. The near-ultraviolet absorption of indole and their derivatives is generally attributed to two strongly overlapping $\pi \rightarrow \pi^{*}$ transitions, ${ }^{30-32}$ with an average $\varepsilon$ value for nonsubstituted indole of $5550 \mathrm{M}^{-1} \mathrm{~cm}^{-1}$, which also justifies its relatively high fluorescence quantum yield. $^{33}$ The tetracyclic indole derivatives prepared, BTIN and BFIN, have also a carboxylate group and it is known that many carbonyl compounds exhibit low fluorescence quantum yields due to the low-lying $n \rightarrow \pi^{*}$ state. In these new indole fused derivatives it is possible that electronic transitions $\pi \rightarrow \pi^{*}$ and $\mathrm{n} \rightarrow \pi^{*}$ can be nearby in energy, resulting in state-mixing. ${ }^{34}$ A predominance of $\mathrm{n} \rightarrow \pi^{*}$ character for the lowest energy transition of BFIN could explain the decrease in $\varepsilon$ values for this compound (Table 1). It is also expected that the presence of the two $\mathrm{S}$ atoms in BTIN leads to the increase of singlet $\rightarrow$ triplet $(\mathrm{S} \rightarrow \mathrm{T}$ ) intersystem crossing (ISC) by enhancement of spin-orbit coupling interaction that is usually observed in sulfur containing compounds. ${ }^{34,35}$ This may

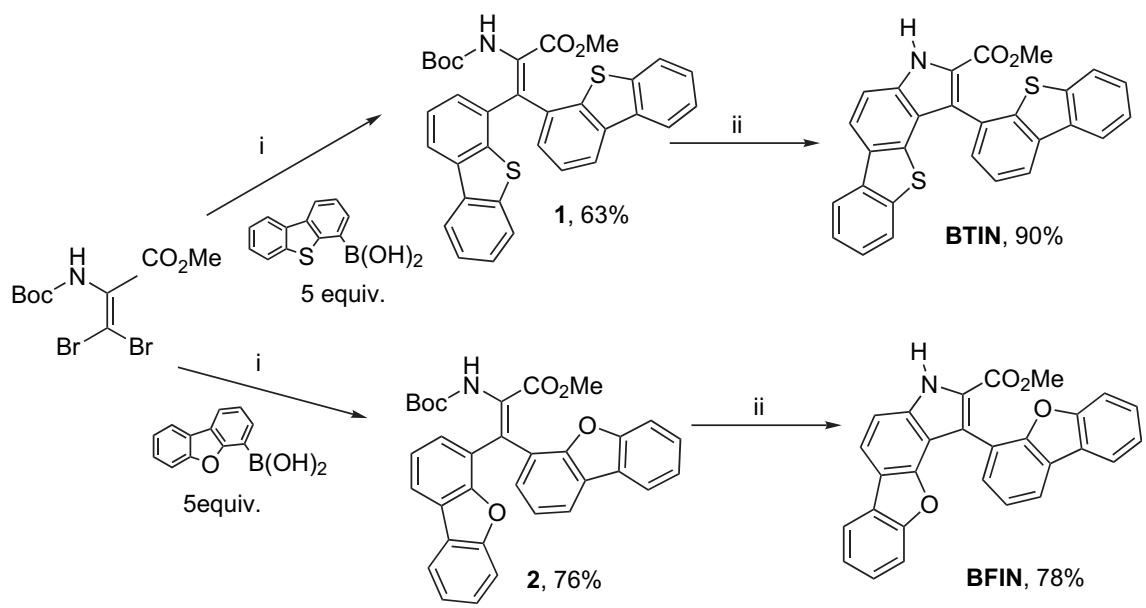

Scheme 1. Synthesis of the bis-Suzuki coupling products $\mathbf{1}$ and 2, and their intramolecular $\mathrm{C}-\mathrm{N}$ cyclization to the tetracyclic compounds BTIN and BFIN. (i) $\mathrm{Pd}(\mathrm{dppf}) \mathrm{Cl}_{2} \cdot \mathrm{CH}_{2} \mathrm{Cl}_{2}$ 1:1 (20 mol \%), $\mathrm{Cs}_{2} \mathrm{CO}_{3}$ (1.4 equiv), THF/ $\mathrm{H}_{2} \mathrm{O}(1: 1), 80^{\circ} \mathrm{C}, 1 \mathrm{~h}$ and $30 \mathrm{~min}$; (ii) $\mathrm{Pd}(\mathrm{OAc})_{2}(50 \mathrm{~mol} \%), \mathrm{Cu}(\mathrm{OAc})_{2} \cdot \mathrm{H}_{2} \mathrm{O}(3 \mathrm{equiv}), \mathrm{DMF}$, $130^{\circ} \mathrm{C}, 3 \mathrm{~h}$. 
Table 1

Absorption and emission maxima wavelengths, molar extinction coefficients and fluorescence quantum yields of BTIN and BFIN in several solvents

\begin{tabular}{|c|c|c|c|c|c|c|}
\hline \multirow[t]{2}{*}{ Solvent } & \multicolumn{2}{|c|}{$\lambda_{\mathrm{abs}} / \mathrm{nm}\left(\varepsilon / \mathrm{M}^{-1} \mathrm{~cm}^{-1}\right)$} & \multicolumn{2}{|c|}{$\lambda_{\mathrm{em}} / \mathrm{nm}$} & \multicolumn{2}{|l|}{$\Phi_{\mathrm{F}}^{\mathrm{b}}$} \\
\hline & BTIN & BFIN & BTIN & BFIN & BTIN & BFIN \\
\hline Cyclohexane & $\begin{array}{l}321\left(1.19 \times 10^{4}\right) \\
287\left(3.03 \times 10^{4}\right) \\
238\left(4.87 \times 10^{4}\right)\end{array}$ & $\begin{array}{l}332(\mathrm{sh})\left(4.10 \times 10^{3}\right) \\
277\left(3.44 \times 10^{4}\right) \\
248\left(2.20 \times 10^{4}\right)\end{array}$ & 384 & 384 & 0.13 & 0.20 \\
\hline Dichloromethane & $\begin{array}{l}322\left(1.13 \times 10^{4}\right) \\
287\left(3.01 \times 10^{4}\right) \\
237\left(4.74 \times 10^{4}\right)\end{array}$ & $\begin{array}{l}334(\mathrm{sh})\left(5.47 \times 10^{3}\right) \\
278\left(4.80 \times 10^{4}\right) \\
249\left(3.18 \times 10^{4}\right)\end{array}$ & 404 & 407 & 0.10 & 0.20 \\
\hline DMF & $\begin{array}{l}323\left(1.52 \times 10^{4}\right) \\
287\left(4.35 \times 10^{4}\right)^{\mathrm{a}}\end{array}$ & $335(\mathrm{sh})\left(7.52 \times 10^{3}\right)^{\mathrm{a}}$ & 394 & 405 & 0.13 & 0.21 \\
\hline DMSO & $324\left(1.68 \times 10^{4}\right)^{\mathrm{a}}$ & $335(\mathrm{sh})\left(7.35 \times 10^{3}\right)^{\mathrm{a}}$ & 398 & 407 & 0.10 & 0.13 \\
\hline Ethanol & $\begin{array}{l}325\left(1.26 \times 10^{4}\right) \\
287\left(3.43 \times 10^{4}\right) \\
237\left(5.78 \times 10^{4}\right)\end{array}$ & $\begin{array}{l}337(\mathrm{sh})\left(6.13 \times 10^{3}\right) \\
277\left(5.30 \times 10^{4}\right) \\
249\left(3.59 \times 10^{4}\right)\end{array}$ & 419 & 426 & 0.11 & 0.30 \\
\hline Methanol & $\begin{array}{l}325\left(1.45 \times 10^{4}\right) \\
287\left(3.73 \times 10^{4}\right) \\
236\left(6.48 \times 10^{4}\right)\end{array}$ & $\begin{array}{l}337(\mathrm{sh})\left(6.02 \times 10^{3}\right) \\
276\left(5.58 \times 10^{4}\right) \\
249\left(3.69 \times 10^{4}\right)\end{array}$ & 425 & 436 & 0.10 & 0.24 \\
\hline
\end{tabular}

a Solvents cut-off: DMF $275 \mathrm{~nm}$; DMSO $270 \mathrm{~nm}$.

b Excitation wavelengths: BTIN $325 \mathrm{~nm}$; BFIN $335 \mathrm{~nm}$.

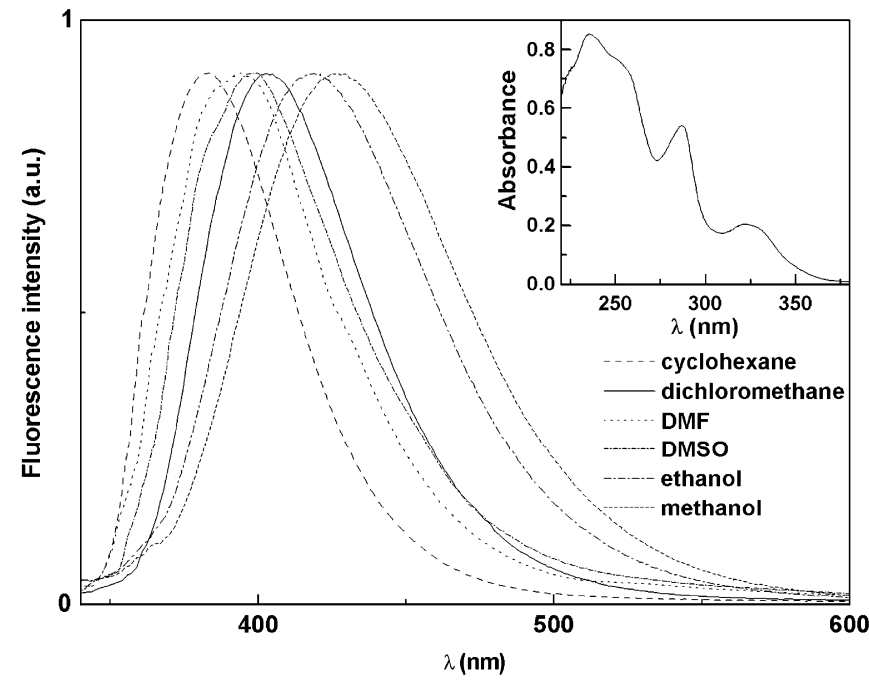

Figure 1. Normalized fluorescence (at peak of maximum energy) spectra of $5 \times 10^{-6} \mathrm{M}$ solutions of BTIN in several solvents $\left(\lambda_{\mathrm{exc}}=325 \mathrm{~nm}\right)$. Inset: absorption spectra of a $1.8 \times 10^{-5} \mathrm{M}$ solution of BTIN in dichloromethane, as an example.

explain why the fluorescence quantum yields of BFIN are higher than those of BTIN in all solvents studied.

The fluorescence emission maximum $\left(\lambda_{\mathrm{em}}\right)$ of both compounds displays a significant red shift from cyclohexane to more polar solvents, while in absorption the red shift is very low (Table 1). This shows that solvent relaxation after photoexcitation plays an important role. The red shift in emission is particularly significant in alcohols, probably due to hydrogen bond formation between these two fluorophores and protic solvents. An increase in $\Phi_{\mathrm{F}}$ value is observed for BFIN in alcohols relative to the other solvents. One possible explanation is that, with increasing solvent polarity and/or hydrogen bonding capability, $\pi \rightarrow \pi^{*}$ state can shift to lower energy than $n \rightarrow \pi^{*}$ state. $^{36}$

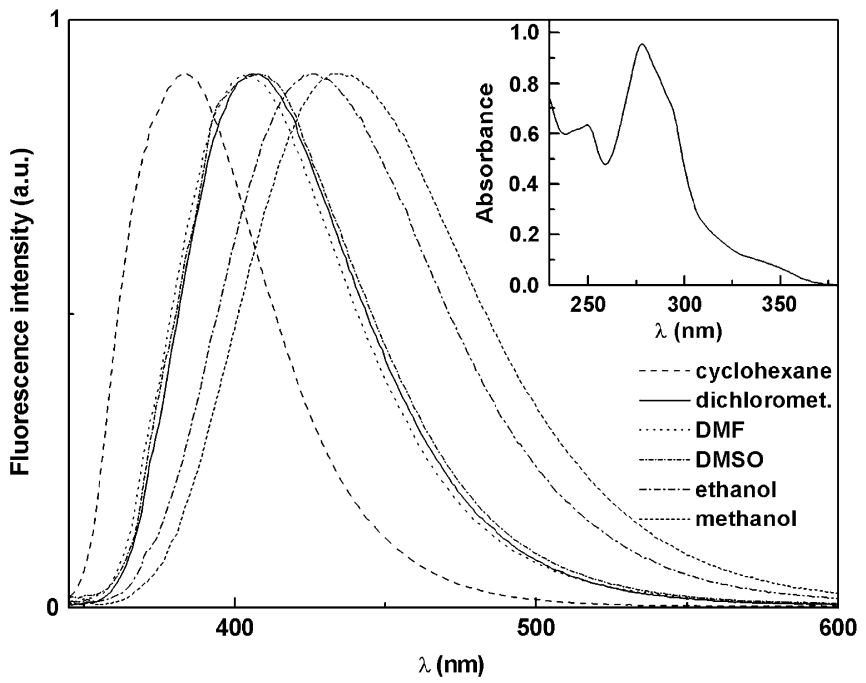

Figure 2. Normalized fluorescence (at peak of maximum energy) spectra of $5 \times 10^{-6} \mathrm{M}$ solutions of BFIN in several solvents $\left(\lambda_{\mathrm{exc}}=335 \mathrm{~nm}\right)$. Inset: absorption spectra of a $2 \times 10^{-5} \mathrm{M}$ solution of BFIN in dichloromethane, as an example.

Both BTIN and BFIN may be used as fluorescent environment sensitive probes, keeping reasonable fluorescence quantum yield values in all solvents studied.

\subsubsection{In the presence of $d s D N A$}

Figure 3 shows the absorption spectra of BTIN in the presence of dsDNA, with increasing [DNA]/[BTIN] ratios (keeping [BTIN] constant), in Tris $-\mathrm{HCl}$ buffer $(\mathrm{pH}=7.4)$. An isosbestic point at $340 \mathrm{~nm}$ is observed, which is characteristic of the presence of two different species and therefore evidences the binding of BTIN to DNA. A DNA-BTIN complex with a maximum absorption at $357 \mathrm{~nm}$ is formed with increasing DNA concentration (Fig. 3). 


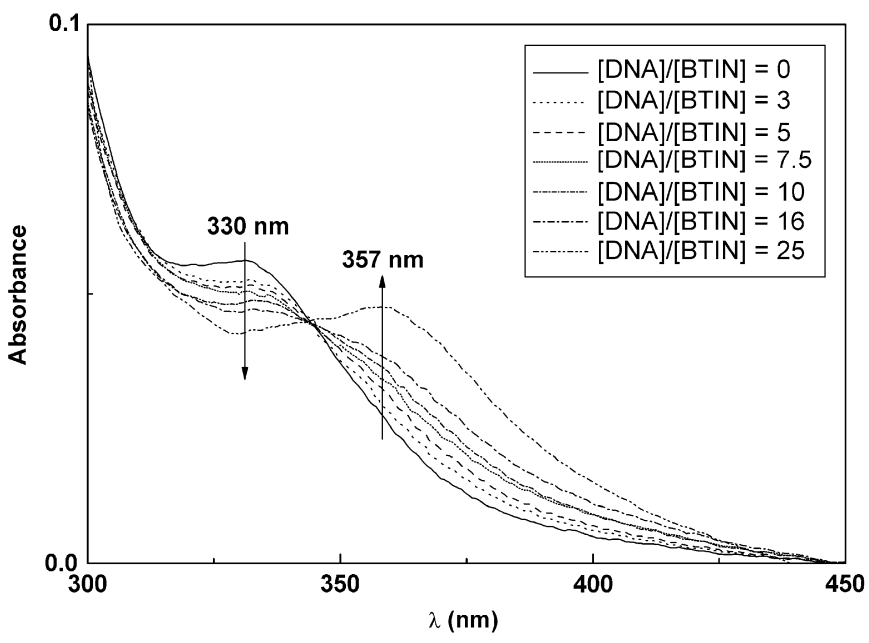

Figure 3. Absorption spectra of BTIN $\left(4.2 \times 10^{-6} \mathrm{M}\right)$ in the presence of different DNA concentrations with increasing $[\mathrm{DNA}] /[\mathbf{B T I N}]$ ratios.

An increase in emission intensity with increasing [DNA]/ [BTIN] ratio, together with a red shift in emission maximum $(10 \mathrm{~nm})$, is observed (Fig. 4) showing that the DNA-BTIN complex has a higher fluorescence quantum yield than the free compound.

A different behaviour is observed for BFIN in the presence of DNA. Figure 5 shows the fluorescence and absorption spectra (the latter as inset) of BFIN in the presence of dsDNA, for several values of the $[\mathrm{DNA}] /[\mathbf{B F I N}]$ ratio. As for BTIN, an increase in emission with increasing [DNA]/[BFIN] ratio is observed but this rise is much smaller. The variations in absorption spectra are negligible, with no spectral evidences of the formation of a DNA-BFIN complex (inset of Fig. 5). The results obtained suggest that BTIN presents a higher degree of intercalation in double-stranded DNA than BFIN, which is probably due to the ability of the $\mathrm{S}$ atoms to establish long distance hydrogen bonds.

For both compounds, full saturation (corresponding to spectral invariance with increasing DNA concentration) is

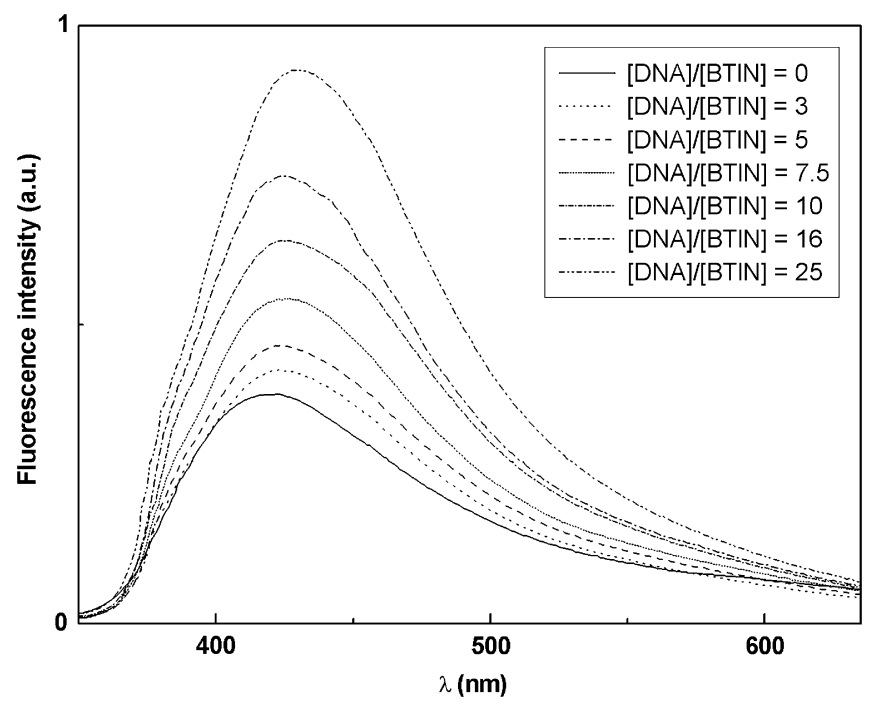

Figure 4. Fluorescence spectra of BTIN $\left(4.2 \times 10^{-6} \mathrm{M}\right)$ in the presence of DNA with increasing [DNA]/[BTIN] $\operatorname{ratios}\left(\lambda_{\mathrm{exc}}=340 \mathrm{~nm}\right)$.

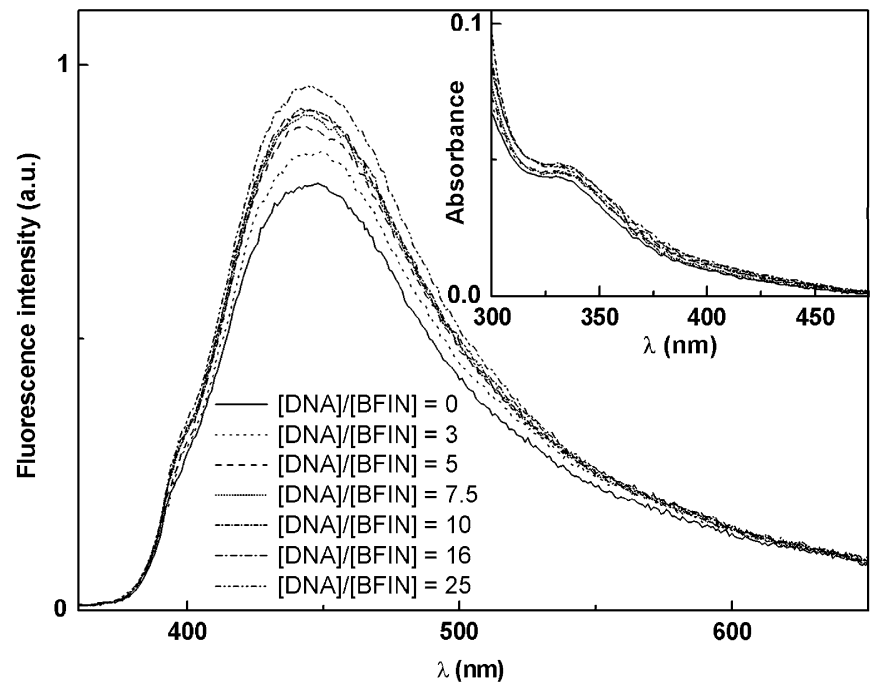

Figure 5. Fluorescence spectra of BFIN $\left(4.2 \times 10^{-6} \mathrm{M}\right)$ in the presence of DNA, with increasing [DNA]/[BFIN] ratios $\left(\lambda_{\mathrm{exc}}=345 \mathrm{~nm}\right)$. Inset: corresponding absorption spectra.

attained at $[\mathrm{DNA}] /[$ compound $]=25$, meaning that total binding is achieved at this ratio.

Binding parameters can be obtained using the modified Scatchard plot, given by McGhee and von Hippel (Eq. 1). ${ }^{37}$

$\frac{r}{c_{\mathrm{f}}}=K_{\mathrm{i}}(1-n r)[(1-n r) /(1-(n-1) r)]^{n-1}$

where $K_{\mathrm{i}}$ is the intrinsic binding constant, $n$ is the binding site size in base pairs, $r$ is the $c_{\mathrm{b}} /[\mathrm{DNA}]$ ratio (in base pairs) and $c_{\mathrm{b}}$ and $c_{\mathrm{f}}$ are the concentrations of bound and free compound, respectively.

The binding data were obtained from fluorescence measurements (Eq. 2) as fluorescence intensity, $I_{\mathrm{F}}$, is proportional to concentration in our experimental conditions (absorbance at excitation wavelength is lower than 0.1).

$c_{\mathrm{b}}=\frac{I_{\mathrm{F}, 0}-I_{\mathrm{F}}}{I_{\mathrm{F}, 0}-I_{\mathrm{F}, \mathrm{b}}} \times c_{\mathrm{total}}$

where $I_{\mathrm{F}, 0}$ is the fluorescence intensity of the free compound, $I_{\mathrm{F}, \mathrm{b}}$ is the fluorescence intensity of the DNA bound compound obtained at total binding and $c_{\text {total }}=c_{\mathrm{f}}+c_{\mathrm{b}}$. The data were treated by least squares methods to determine the values of the binding constants and binding site sizes (Table 2).

The higher $n$ value for BTIN can be justified by the larger size of the $\mathrm{S}$ atom. BTIN binding constant indicates a higher affinity of this compound for DNA base pairs (Table 2).

From the fluorescence spectra, it is possible to estimate the ratio between the emission quantum yields of DNA-BTIN

Table 2

Values of the binding constants $\left(K_{\mathrm{i}}\right)$ and binding site sizes in base pairs $(n)$ for the interaction of BTIN and BFIN with DNA

\begin{tabular}{lll}
\hline Compound & $K_{\mathrm{i}}\left(\mathrm{M}^{-1}\right)$ & $n$ \\
\hline BTIN & $(3.8 \pm 0.3) \times 10^{5}$ & $6.1 \pm 1.8$ \\
BFIN & $(1.3 \pm 0.1) \times 10^{5}$ & $4.1 \pm 1.2$ \\
\hline
\end{tabular}


complex, $\Phi_{\text {DNA-BTIN }}$, and of free BTIN, $\Phi_{\text {BTIN }}$. The ratio between the emission quantum yields in the presence and absence of DNA, $\Phi_{\mathrm{F}} / \Phi_{\mathrm{F}, 0}$, is given by Eq. 3:

$\frac{\Phi_{\mathrm{F}}}{\Phi_{\mathrm{F}, 0}}=\frac{\Phi_{\text {BTIN }} \varepsilon_{\mathbf{B T I N}} b c_{\mathrm{f}}+\Phi_{\text {DNA-BTIN }} \varepsilon_{\text {DNA-BTIN }} b c_{\mathrm{b}}}{\Phi_{\text {BTIN }} \varepsilon_{\text {BTIN }} b c_{\text {total }}}$

where the subscript 0 means the absence of DNA, $\varepsilon_{\mathbf{B T I N}}$ and $\varepsilon_{\text {DNA-BTIN }}$ are the molar absorptivities of free BTIN and DNA-BTIN complex, respectively, $b$ is the path length and $c_{\mathrm{f}}$ and $c_{\mathrm{b}}$ are the concentrations of free and bound compound, respectively.

For excitation at isosbestic point $(340 \mathrm{~nm})$ where bound and free BTIN molecules have the same molar absorptivity, Eq. 3 simplifies to Eq. 4 :

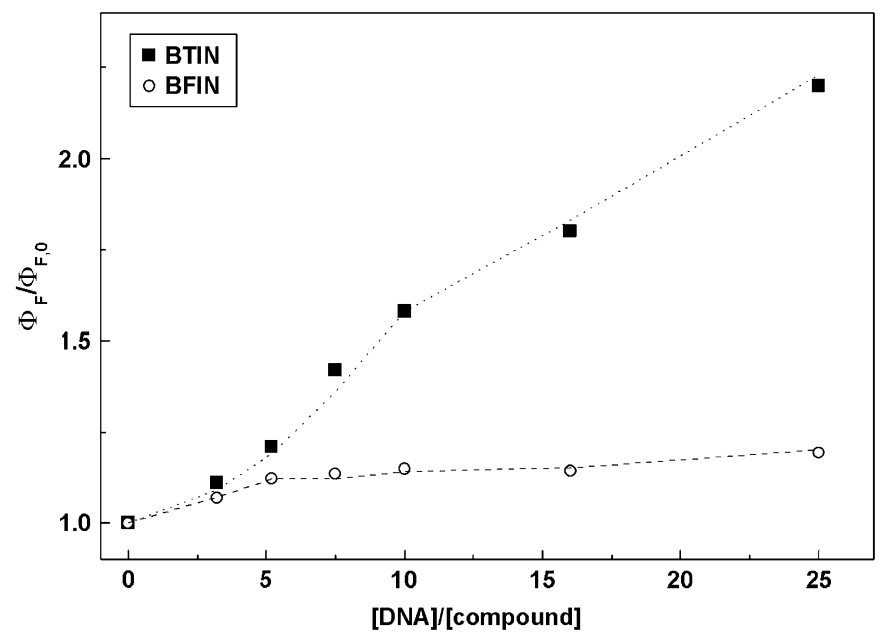

Figure 6. Ratio between the emission quantum yields in the presence and absence of DNA, with increasing [DNA]/[compound] values. The dotted lines represent the best fit to the experimental data.
$\frac{\Phi_{\mathrm{F}}}{\Phi_{\mathrm{F}, 0}}=\frac{\Phi_{\text {BTIN }} c_{\mathrm{f}}+\Phi_{\mathrm{DNA}-\mathrm{BTIN}} c_{\mathrm{b}}}{\Phi_{\text {BTIN }}\left(c_{\mathrm{f}}+c_{\mathrm{b}}\right)}$

A similar treatment can be done for BFIN fluorescence data, if the small differences between the absorption spectra are neglected.

Figure 6 displays the plot of $\Phi_{\mathrm{F}} / \Phi_{\mathrm{F}, 0}$ as function of [DNA] $/$ [compound] ratio.

The best fit of Eq. 4 to the experimental data gives $\Phi_{\text {DNA-BTIN }} / \Phi_{\text {BTIN }}=2.3$ and $\Phi_{\text {DNA-BFIN }} / \Phi_{\text {BFIN }}=1.2$, meaning that the fluorescence quantum yield increases 2.3 times and 1.2 times, respectively, upon binding of BTIN or BFIN to DNA.

Fluorescence quenching experiments with iodide ion were also performed for BTIN and BFIN in the presence of DNA. The measurements were performed at ratio [DNA]/ $[$ compound] $=25$. The quenching data were first plotted according to the Stern-Volmer relation (Eq. 5): ${ }^{36}$

$\frac{I_{0}}{I}=1+K_{\mathrm{SV}}[\mathrm{Q}]$

where $I_{0}$ and $I$ are, respectively, the fluorescence intensities in the absence and in the presence of quencher $\left(\mathrm{I}^{-}\right), K_{\mathrm{SV}}$ is the Stern-Volmer constant and $[\mathrm{Q}]$ is the quencher concentration.

Stern-Volmer plots are nonlinear (Fig. 7A), with a downward curvature, which means that not all the fluorescent molecules are accessible to the quencher. In this case, the system contains heterogeneously emitting sites (some molecules are accessible to the quencher and others are not) and the Stern-Volmer equation must be modified ${ }^{38}$ as Eq. 6:

$$
\frac{I_{0}}{\Delta I}=\frac{1}{f_{\mathrm{a}}}+\frac{1}{f_{\mathrm{a}} K_{\mathrm{SV}}[\mathrm{Q}]}
$$
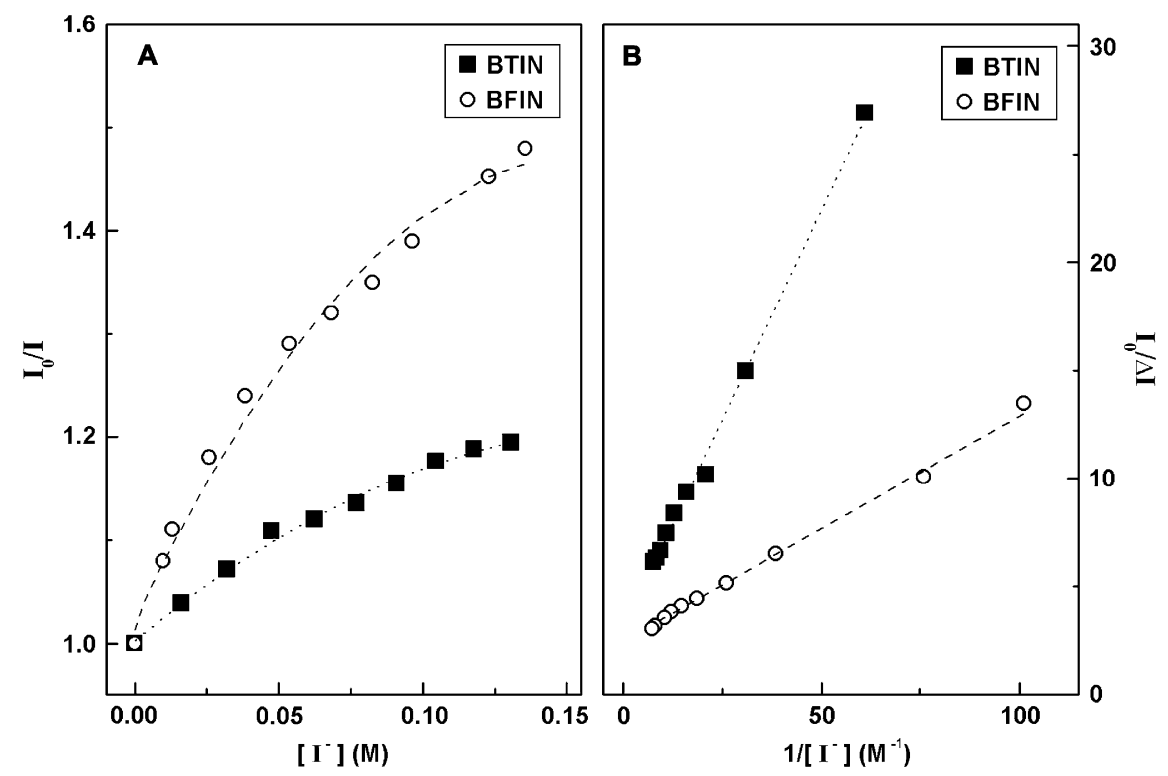

Figure 7. (A) Stern-Volmer plots for quenching with iodide ion $\left(\mathrm{I}^{-}\right)$of BTIN and BFIN in the presence of salmon sperm DNA, for $[\mathrm{DNA}] /[\mathrm{compound}]=25$. (B) Corresponding modified Stern-Volmer plots. 
Table 3

Values of the accessibilities $\left(f_{\mathrm{a}}\right)$ to the quencher $\left(\mathrm{I}^{-}\right)$and Stern-Volmer constants for BTIN and BFIN bound to DNA, for $[\mathrm{DNA}] /[$ compound] $=25$

\begin{tabular}{lcc}
\hline Compound & $K_{\mathrm{SV}}\left(\mathrm{M}^{-1}\right)$ & $f_{\mathrm{a}}$ \\
\hline BTIN & 7.7 & 0.33 \\
BFIN & 19.6 & 0.45 \\
\hline
\end{tabular}

where $\Delta I=I_{0}-I$ and $f_{\mathrm{a}}$ is the accessibility to the quencher. From the plots of $I_{0} / \Delta I$ versus $1 /[\mathrm{Q}]$, it is possible to obtain the compound accessibilities to the quencher (Fig. 7B, Table 3).

The results in Table 3 show that for BFIN and BTIN, respectively, $55 \%$ and $67 \%$ of the emitting sites are located inside the double helix and, thus, are not accessible to the external quencher, indicating that the intercalative binding is the preferred form of association of these compounds to DNA. As BTIN and BFIN are neutral molecules, electrostatic binding to the nucleic acid is not expected to occur in a large extent. Therefore, the fraction of molecules accessible to the external quencher $\left(f_{\mathrm{a}}\right)$ should correspond mainly to bound molecules at the grooves.

The values of the Stern-Volmer constants, $K_{\mathrm{SV}}$, indicate that the quenching process by iodide ion is more efficient for BFIN than for BTIN. This confirms that BTIN is the more intercalative compound in DNA.

\subsection{Electrochemical studies of dsDNA interaction with BTIN}

The interaction of BTIN with dsDNA was also studied by electrochemical methods.
The changes at the oxidation signals of BTIN and of the electroactive DNA base, adenine, were monitored electrochemically using differential pulse voltammetry (DPV) technique (Fig. 8).

The oxidation signals of BTIN before and after interaction with dsDNA were measured at almost $+180 \mathrm{mV}$ (Fig. 9A). The oxidation signals of the electroactive adenine DNA base observed at $\sim+1280 \mathrm{mV}$ were also measured before and after interaction with BTIN at disposable PGE (Fig. 9B). Additionally, another small and not reproducible oxidation signal of BTIN was observed at $\sim+950 \mathrm{mV}$ (not shown) that is similar
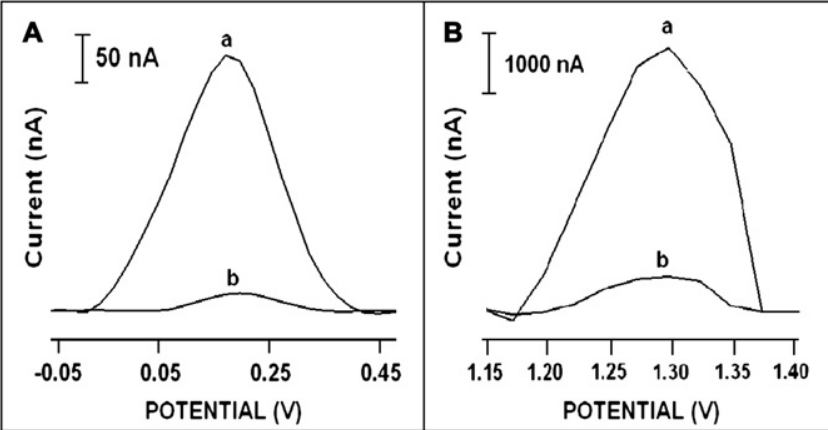

Figure 9. Differential pulse voltammograms for oxidation signals of BTIN (A) and adenine (B) obtained from interaction of $50 \mu \mathrm{g} / \mathrm{mL}$ of BTIN with $16 \mu \mathrm{g} / \mathrm{mL}$ of dsDNA; (a) before and (b) after interaction. Pre-treatment of PGE surface by applying $+1.4 \mathrm{~V}$ for $30 \mathrm{~s}$ in ABS; DNA immobilization by dip-coating procedure for $7.5 \mathrm{~min}$; interaction for $5 \mathrm{~min}$ at open circuit potential; DPV measurement performed by scanning from -0.20 to $+1.40 \mathrm{~V}$ at $50 \mathrm{mV}$ pulse amplitude and $50 \mathrm{mV} / \mathrm{s}$ scan rate.

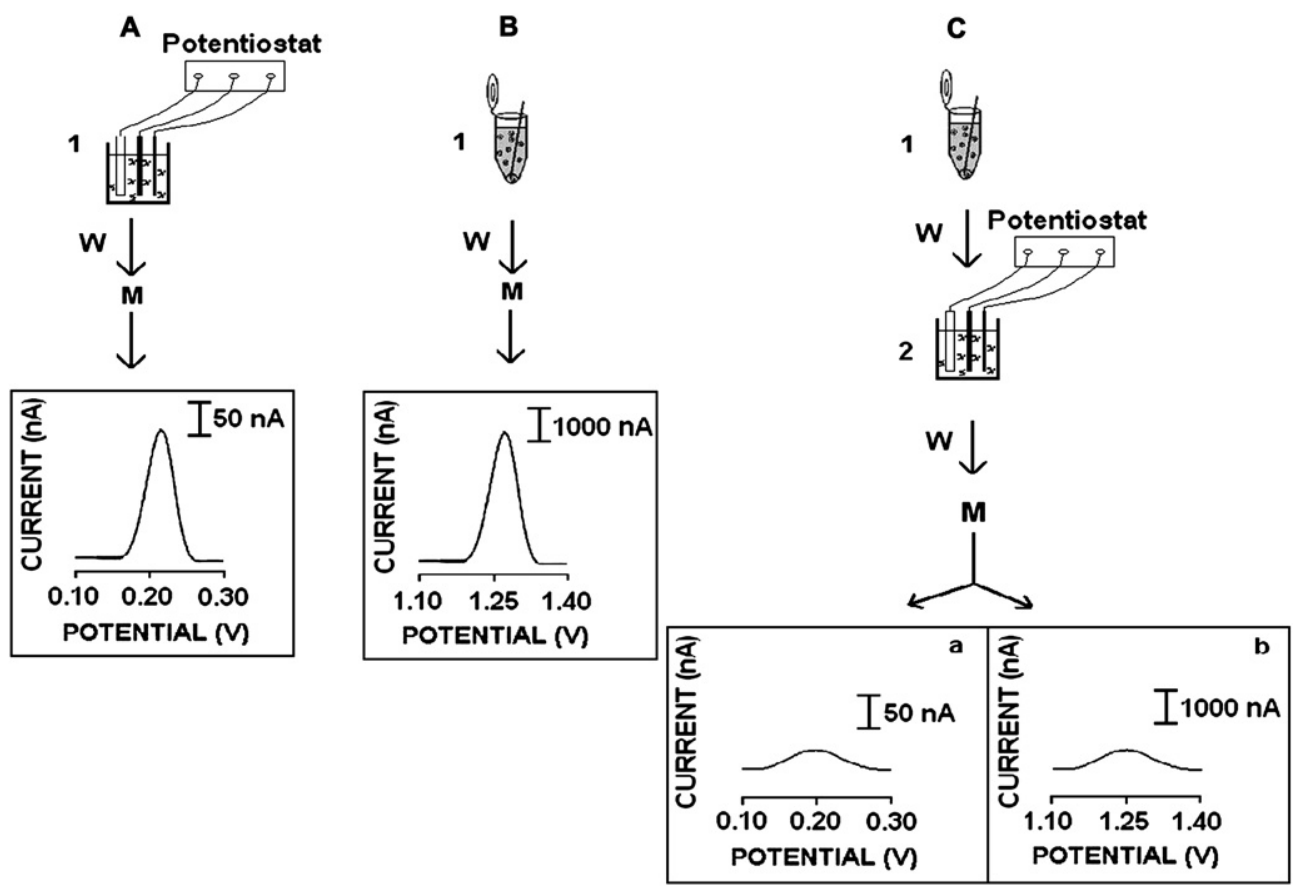

Figure 8. Electrochemical detection of BTIN-DNA interaction using DPV. (A) Detection of oxidation signal of BTIN: (1) $50 \mu \mathrm{g} / \mathrm{mL}$ of BTIN accumulated onto PGE at open circuit potential for $5 \mathrm{~min}$. (B) Detection of oxidation signal of adenine: (1) DNA immobilization by wet-adsorption in $16 \mu \mathrm{g} / \mathrm{mL} \mathrm{dsDNA}$ for $7.5 \mathrm{~min}$. (C) Detection of interaction of BTIN with dsDNA by measuring the oxidation signals of BTIN and adenine in the same batch: (1) same as in (B) and (2) $50 \mu \mathrm{g} / \mathrm{mL}$ of BTIN accumulation onto dsDNA modified PGE at open circuit potential for $5 \mathrm{~min}$ followed by the measurement process (M); (a) BTIN oxidation signal, (b) adenine oxidation signal. W: washing step using ABS; M: measurement step in ABS by using DPV scanning between +0.1 and $+1.4 \mathrm{~V}$ at scan rate $50 \mathrm{mV} / \mathrm{s}$ with $50 \mathrm{mV}$ modulation amplitude. 
to the peak potential of DNA base, guanine by overlapping to its peak potential at $+1070 \mathrm{mV}$. Because of this, we focused on the changes at the oxidation signals of BTIN and adenine obtained with the dsDNA modified PGE. A gradual decrease at both oxidation signals of BTIN and adenine after interaction was observed.

A series of three repetitive DPV signals obtained with 50 and $16 \mu \mathrm{g} / \mathrm{mL}$ of BTIN and of dsDNA, respectively, at PGE surface resulted in reproducible results namely a mean response of $289.3 \mathrm{nA}$ for BTIN and $5092 \mathrm{nA}$ for adenine, with a relative standard deviation $(n=3)$ of $12.1 \%$ and $18.5 \%$, respectively.

In Figure 10 the changes at the oxidation signals of BTIN and adenine before and after interaction of BTIN in different concentrations 10,30 and $50 \mu \mathrm{g} / \mathrm{mL}$ with $16 \mu \mathrm{g} / \mathrm{mL}$ of dsDNA at PGE surface are presented. When the concentration of BTIN was increased in the absence of interaction, a gradual increase at the oxidation signal for BTIN was observed (Fig. 10B). A decrease at the oxidation signals of BTIN and adenine was observed after interaction (Fig. 10C).

A dramatic decrease $(\sim 95 \%)$ was observed at the signal of BTIN after interaction of $50 \mu \mathrm{g} / \mathrm{mL}$ of this compound with dsDNA (Fig. 10B and C3). When the concentration of BTIN was 30 and $10 \mu \mathrm{g} / \mathrm{mL}$, it is still observed a high ratio $77 \%$ and $52 \%$ of decrease, respectively, after its interaction with dsDNA (Fig. 10B and $\mathrm{C} 1-\mathrm{C} 2$ ).

A decrease at adenine oxidation signals was also observed, to about $20 \%, 54 \%$ and $89 \%$ in the presence of the same concentrations of BTIN, 10, 30 and $50 \mu \mathrm{g} / \mathrm{mL}$, respectively, after its interaction with dsDNA (Fig. 10A and C1-C3). The highest decrease at the oxidation signals of BTIN and adenine was obtained at $50 \mu \mathrm{g} / \mathrm{mL}$ of BTIN, and this was considered as the optimum concentration to detect the interaction of BTIN with dsDNA.

The decrease of the magnitude of adenine oxidation signal obtained after interaction of BTIN with dsDNA (shown in Fig. 10) may be attributed to the intercalation of this compound into the base pairs of DNA. This phenomenon could be explained by the shielding of oxidizable groups of

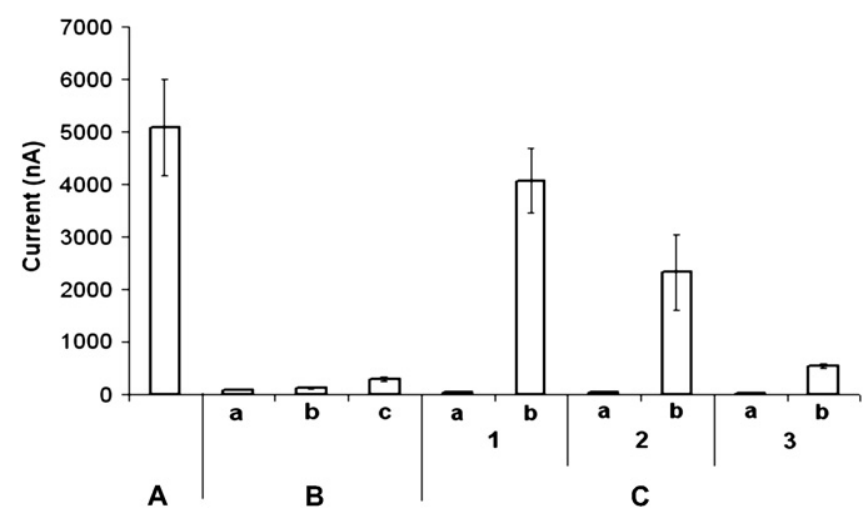

Figure 10. Histograms of the oxidation signals of BTIN and adenine. (A) Adenine signal in the absence of BTIN, (B) the signals of BTIN in different concentrations: (a) 10 , (b) 30 and (c) $50 \mu \mathrm{g} / \mathrm{mL}$ before interaction with dsDNA and (C) the signals of BTIN (a) and adenine (b) obtained after interaction of dsDNA and BTIN in different concentrations: (1)10, (2) 30 and (3) $50 \mu \mathrm{g} / \mathrm{mL}$. The conditions used were the same as described in Figure 8. electroactive base adenine while BTIN interacts with the double helix of DNA at the electrode surface by intercalation. The decrease of the oxidation signal of BTIN indicates a possible damage in the oxidizable groups of this compound after intercalation. The decrease of the adenine oxidation signals obtained using dsDNA is in good agreement to some of our results $^{22}$ and to the results presented by Oliveira Brett et al. ${ }^{23}$ Thus, we may explain this decrease as the preferential binding of BTIN to the electroactive base adenine.

In contrast to earlier studies performed by using different electrochemical transducers such as, glassy carbon electrode (GCE), hanging mercury drop electrode (HMDE) and wellknown drugs, e.g., Mitoxantrone (MTX) and Doxorubicin (DXR), the electrochemical sensing of interaction of BTIN with dsDNA was successfully performed here in a lower concentration of DNA and in a shorter time, taking advantage of single-use graphite sensor technology. Oliveira Brett et al. ${ }^{24}$ presented a report for the determination of the interaction of the anthraquinone drug MTX with dsDNA or ssDNA at higher concentrations. The interaction was studied in an aqueous medium or on electrode surface by using GCE in connection with the use of square-wave voltammetry (SWV) and DPV. The intercalation was determined by the significant changes on MTX oxidation signal, guanine and adenine signals after interaction with DNA. Studies by Fojta et al. ${ }^{25}$ on conformational changes of DNA due to the binding of intercalators such as the anticancer agent DXR, by using adsorptive transfer stripping alternative current voltammetry at HMDE showed less than $40 \%$ and $30 \%$ decrease at DXR $(50 \mu \mathrm{M})$ peak using $30 \mu \mathrm{g} / \mathrm{mL}$ ssDNA and dsDNA, respectively. In our study, the detection limit for BTIN estimated from $S / N=3$ was 1.13 and $15 \mu \mathrm{g} / \mathrm{mL}$, before and after interaction with $16 \mu \mathrm{g} / \mathrm{mL}$ dsDNA at PGE surface in 5 min accumulation time.

\section{Conclusions}

Two new tetracyclic compounds were synthesized in high yields (BTIN and BFIN) by an intramolecular $\mathrm{C}-\mathrm{N}$ metalassisted cyclization, developed by us, of the also new $\beta, \beta$-diheteroaryldehydroalanine derivatives. The latter were prepared by a bis-Suzuki coupling of a $\beta, \beta$-dibromodehydroalanine derivative and dibenzothien-4-yl and dibenzofur-4-yl boronic acids.

The absorption and fluorescence properties of BTIN and BFIN were studied in several solvents showing that both compounds may be used as fluorescence probes. The same type of studies was performed in the presence of salmon sperm dsDNA. The binding constants of both compounds were determined, showing that BTIN has a higher affinity for DNA. The preferential intercalation mode of binding was confirmed by fluorescence quenching experiments with iodide ion, which indicated a low accessibility of BTIN to the quencher.

The electrochemical and spectrophotometric detections of interaction of BTIN with dsDNA were successfully explored in this study and the results were in a good agreement with each other. The electrochemical detection of BTIN interaction with dsDNA was performed by using faster, more sensitive and less laborious electrochemical technique with the advantages 
of using disposable graphite sensor (PGE) technology. The success of PGE over existing carbon electrodes is its commercial availability and its improved reproducibility. The electrochemical method presented here is experimentally convenient and sensitive requiring only small amounts of materials.

The analysis of novel DNA-targeted compounds in vitro is very important for the discovery of new pharmaceuticals. In comparison to other methodologies in the literature, no data were reported concerning the evaluation of both electrochemical and spectroscopic detections of interaction of any new DNA-targeted compound with nucleic acids. Such experiments allow the understanding of the interaction in order to determine the recognition of DNA sites, and also promote novel drugs' rational design for application in chemotherapy, and in the development of new tools for the point-of-care tests and diagnosis based on DNA.

\section{Experimental section}

\subsection{Synthesis}

\subsubsection{General considerations}

Melting points $\left({ }^{\circ} \mathrm{C}\right)$ were determined in a Gallenkamp apparatus and are uncorrected. ${ }^{1} \mathrm{H}$ and ${ }^{13} \mathrm{C}$ NMR spectra were recorded at 300 and $75.4 \mathrm{MHz}$, respectively. Heteronuclear correlations ${ }^{1} \mathrm{H},{ }^{13} \mathrm{C}, \mathrm{HMQC}$ and $\mathrm{HMBC}$ were also performed. MS and HRMS data were recorded using a direct injection method by Electron Impact. The reactions were monitored by thin layer chromatography (TLC). Column chromatography was performed on Macherey-Nagel silica gel 230-400 mesh. Petroleum ether refers to the boiling range $40-60{ }^{\circ} \mathrm{C}$. Ether refers to diethyl ether. When solvent gradient was used, the increase of polarity was made from neat petroleum ether to mixtures of ether/petroleum ether, increasing $10 \%$ of ether each time until the isolation of the product. Boronic acids and caesium carbonate were purchased from Aldrich. $\mathrm{Pd}(\mathrm{dppf}) \mathrm{Cl}_{2} \cdot \mathrm{CH}_{2} \mathrm{Cl}_{2}$ 1:1 (palladium 1,1'-diphenylphosphaneferrocene-dichloromethane adduct) was purchased from STREM.

\subsubsection{General procedure for the synthesis of compounds 1 and 2 by bis-Suzuki coupling}

To a solution of $N$-Boc- $\beta, \beta$-dibromodehydroalanine methyl $\operatorname{ester}^{26 \mathrm{a}}(180 \mathrm{mg}, 0.500 \mathrm{mmol})$ in $\mathrm{THF} / \mathrm{H}_{2} \mathrm{O}(5 \mathrm{~mL}: 5 \mathrm{~mL})$, dibenzothien-4-yl boronic acid or dibenzofur-4-yl boronic acid (5 equiv), $\mathrm{Cs}_{2} \mathrm{CO}_{3}$ (1.4 equiv) and $\mathrm{Pd}(\mathrm{dppf}) \mathrm{Cl}_{2} \cdot \mathrm{CH}_{2} \mathrm{Cl}_{2}$ $(20 \mathrm{~mol} \%)$ were added and the mixture was heated at $80^{\circ} \mathrm{C}$ for $1 \mathrm{~h}$ and $30 \mathrm{~min}$. The reaction was stopped when no dehydroamino acid was observed in the TLC. After cooling, ethyl acetate $(15 \mathrm{~mL})$ and water $(10 \mathrm{~mL})$ were added and the phases were separated. The organic phase was washed with water and brine $(2 \times 5 \mathrm{~mL})$, and it was dried $\left(\mathrm{MgSO}_{4}\right)$ and filtered. Removal of solvent gave an oily residue, which was subjected to column chromatography.

4.1.2.1. Methyl ester of $N$-(tert-butoxycarbonyl)- $\beta, \beta$-bis(dibenzothien-4-yl)dehydroalanine (1). After column chromatography using solvent gradient from neat petroleum ether to $20 \%$ ether/petroleum ether, compound 1 (179 mg, 63\%) was obtained as a yellow oil that crystallized from ether/petroleum ether as white crystals, mp $214-216{ }^{\circ} \mathrm{C} .{ }^{1} \mathrm{H}$ NMR $\left(300 \mathrm{MHz}, \mathrm{CDCl}_{3}\right): \delta=1.44\left(9 \mathrm{H}, \mathrm{s}, \mathrm{CH}_{3} \mathrm{Boc}\right), 3.47(3 \mathrm{H}, \mathrm{s}$, OMe), $6.12(1 \mathrm{H}$, br s, NH), 7.31-7.56 (8H, m, ArH), 7.60$7.65(1 \mathrm{H}, \mathrm{m}, \mathrm{ArH}), 7.79-7.85(1 \mathrm{H}, \mathrm{m}, \mathrm{ArH}), 8.08-8.22$ $(4 \mathrm{H}, \mathrm{m}, \mathrm{ArH}) \mathrm{ppm} .{ }^{13} \mathrm{C}$ NMR $\left(75.4 \mathrm{MHz}, \mathrm{CDCl}_{3}\right): \delta=28.07$ $\left(\mathrm{C}\left(\mathrm{CH}_{3}\right)_{3}\right), 52.25\left(\mathrm{OCH}_{3}\right), 81.62\left(\mathrm{OC}\left(\mathrm{CH}_{3}\right)_{3}\right), 121.43(\mathrm{CH})$, $121.48(\mathrm{CH}), 121.73(\mathrm{CH}), 121.95(\mathrm{CH}), 122.62(2 \times \mathrm{CH})$, $122.73(\mathrm{C}), 124.17(\mathrm{CH}), 124.23(\mathrm{CH}), 124.39(\mathrm{CH}), 124.89$ $(\mathrm{CH}), 126.41(\mathrm{C}), 126.68(\mathrm{CH}), 126.98(\mathrm{C}), 127.11(\mathrm{CH})$, $127.90(\mathrm{CH}), 129.03(\mathrm{CH}), 130.43(\mathrm{C}), 133.56(\mathrm{C}), 135.13$ (C), 135.35 (C), 136.18 (C), 136.43 (C), 139.71 (C), 139.89 (C), $140.02(\mathrm{C}), 152.60(\mathrm{C}=\mathrm{O}), 165.72(\mathrm{C}=\mathrm{O}) \mathrm{ppm} . \mathrm{MS}$ (EI): $m / z(\%) 567\left(\mathrm{M}^{+}+2,3\right), 566\left(\mathrm{M}^{+}+1,7\right), 565\left(\mathrm{M}^{+}\right.$, 18), $491 \quad\left(\mathrm{M}^{+}-{ }^{t} \mathrm{BuO}, \quad 5\right), 465 \quad\left(\mathrm{M}^{+}-\mathrm{Boc}, 100\right), 405$ $\left(\mathrm{M}^{+}-\mathrm{Boc}-\mathrm{CO}_{2} \mathrm{Me}, 77\right), 377$ (70). HRMS, $\mathrm{M}^{+}$Calcd for $\mathrm{C}_{33} \mathrm{H}_{27} \mathrm{NO}_{4} \mathrm{~S}_{2}$ : 565.1382; found: 565.1387.

4.1.2.2. Methyl ester of $N$-(tert-butoxycarbonyl)- $\beta, \beta$-bis(dibenzofur-4-yl)dehydroalanine (2). After column chromatography using solvent gradient from neat petroleum ether to $30 \%$ ether/petroleum ether, compound 2 (203 mg, 76\%) was obtained as a brownish solid that was washed with ether/petroleum ether to give a beige solid, mp $154-156{ }^{\circ} \mathrm{C} .{ }^{1} \mathrm{H}$ NMR $\left(300 \mathrm{MHz}, \mathrm{CDCl}_{3}\right): \delta=1.41\left(9 \mathrm{H}, \mathrm{s}, \mathrm{CH}_{3} \mathrm{Boc}\right), 3.48(3 \mathrm{H}, \mathrm{s}$, OMe), 6.17 (1H, br s, NH), 7.20-7.58 (10H, m, ArH), 7.88$8.10(4 \mathrm{H}, \mathrm{m}, \mathrm{ArH}) \mathrm{ppm} .{ }^{13} \mathrm{C}$ NMR $\left(75.4 \mathrm{MHz}, \mathrm{CDCl}_{3}\right)$ : $\delta=28.10\left(\mathrm{C}\left(\mathrm{CH}_{3}\right)_{3}\right), 52.04\left(\mathrm{OCH}_{3}\right), 81.07\left(\mathrm{OC}\left(\mathrm{CH}_{3}\right)_{3}\right), 111.76$ $(\mathrm{CH}), 112.03(\mathrm{CH}), 120.47(\mathrm{CH}), 120.60(\mathrm{CH}), 120.65(\mathrm{CH})$, $121.05(\mathrm{CH}), 122.17(\mathrm{C}), 122.58(\mathrm{CH}), 122.73(\mathrm{CH}), 122.93$ $(\mathrm{CH}), 123.10(\mathrm{CH}), 123.66(\mathrm{C}), 123.93(\mathrm{C}), 124.05(\mathrm{C})$, $124.21(\mathrm{C}), 125.00(\mathrm{C}), 127.16(\mathrm{CH}), 127.47(\mathrm{CH}), 128.58$ $(\mathrm{CH}), 128.87(\mathrm{CH}), 129.51(\mathrm{C}), 152.81(\mathrm{C}=\mathrm{O}), 152.93(\mathrm{C})$, 153.90 (C), $155.98(\mathrm{C}), 156.22(\mathrm{C}), 165.54(\mathrm{C}=\mathrm{O}) \mathrm{ppm}$. MS (EI): $m / z(\%) 533\left(\mathbf{M}^{+}, 5\right), 459\left(\mathbf{M}^{+}-{ }^{t} \mathrm{BuO}, 12\right), 433\left(\mathbf{M}^{+}-\mathrm{Boc}\right.$, 93), $373\left(\mathrm{M}^{+}-\mathrm{Boc}-\mathrm{CO}_{2} \mathrm{Me}, 100\right), 345$ (84). HRMS, $\mathrm{M}^{+}$Calcd for $\mathrm{C}_{33} \mathrm{H}_{27} \mathrm{NO}_{6}$ : 533.1838; found: 533.1837 .

\subsubsection{General procedures for the synthesis of BTIN and BFIN}

In a Schlenk tube, to a solution of the $\beta, \beta$-diheteroaryldehydroamino acid 1 or 2 in DMF, $\mathrm{Pd}(\mathrm{OAc})_{2}(50 \mathrm{~mol} \%)$ and $\mathrm{Cu}(\mathrm{OAc})_{2} \cdot \mathrm{H}_{2} \mathrm{O}$ (3 equiv) were added and the mixture was left stirring for $3 \mathrm{~h}$ and $30 \mathrm{~min}$ at $130{ }^{\circ} \mathrm{C}$. After cooling, ethyl acetate was added $(20 \mathrm{~mL})$ and the organic phase was washed with water and brine $(2 \times 25 \mathrm{~mL}$ of each), dried $\left(\mathrm{MgSO}_{4}\right)$ and filtered. Removal of solvent gave an oil.

4.1.3.1. Methyl 1-(dibenzothien-4-yl)-3H-benzothieno[2,3-e]indole-2-carboxylate (BTIN). Compound 1 (125 mg, $0.221 \mathrm{mmol}$ ) in DMF ( $3 \mathrm{~mL}$ ) by following the general procedure gave BTIN as a brownish solid $(92.0 \mathrm{mg}, 90 \%)$, which upon washes with ether gave a beige solid, $\mathrm{mp}>300{ }^{\circ} \mathrm{C} .{ }^{1} \mathrm{H}$ NMR $\left(300 \mathrm{MHz}, \mathrm{CDCl}_{3}\right): \delta=3.69(3 \mathrm{H}, \mathrm{s}, \mathrm{OMe}), 7.27-$ $7.32\left(1 \mathrm{H}, \mathrm{m}\right.$, partially obscured by the signal of $\mathrm{CHCl}_{3}$, $\mathrm{ArH}), 7.38-7.53(3 \mathrm{H}, \mathrm{m}, \mathrm{ArH}), 7.59-7.62(3 \mathrm{H}$, apparent $\mathrm{d}$, 
$J=8.7 \mathrm{~Hz}, \operatorname{ArH}), 7.68-7.73(2 \mathrm{H}, \mathrm{m}, \mathrm{ArH}), 8.12(1 \mathrm{H}, \mathrm{br} \mathrm{d}, J=$ $7.8 \mathrm{~Hz}, \operatorname{ArH}), 8.16(1 \mathrm{H}, \mathrm{d}, J=8.7 \mathrm{~Hz}, 5-\mathrm{H}), 8.28(1 \mathrm{H}, \mathrm{br}$ d, $J=7.8 \mathrm{~Hz}, \operatorname{ArH}), 8.37(1 \mathrm{H}$, br d, $J=7.8 \mathrm{~Hz}, 6-\mathrm{H}), 9.41(1 \mathrm{H}$, br s, NH) ppm. ${ }^{13} \mathrm{C}$ NMR $\left(75.4 \mathrm{MHz}, \mathrm{CDCl}_{3}\right): \delta=52.08\left(\mathrm{OCH}_{3}\right)$, $109.55(\mathrm{CH}), 119.94(\mathrm{CH}), 120.66(\mathrm{CH}), 121.33(\mathrm{CH})$, $121.83(\mathrm{CH}), 122.22(\mathrm{C}), 122.66(\mathrm{CH}), 122.84(\mathrm{CH}), 123.58$ (C), $124.24(2 \times \mathrm{CH}), 124.63(\mathrm{CH}), 125.15(\mathrm{CH}), 126.60$ $(\mathrm{CH}), 128.72(\mathrm{C}), 128.78(\mathrm{CH}), 129.68(\mathrm{C}), 132.77(\mathrm{C})$, 134.66 (C), 134.91 (C), 135.55 (C), 135.61 (C), 136.03 (C), 138.94 (C), 139.84 (C), 141.77 (C), $161.89(\mathrm{C}=\mathrm{O}) \mathrm{ppm}$. MS (EI): $m / z(\%) 465\left(\mathbf{M}^{+}+2,10\right), 464\left(\mathbf{M}^{+}+1,23\right), 463$ $\left(\mathrm{M}^{+}, 67\right), 431$ ( $\left.\mathrm{M}^{+}-\mathrm{OMe}, 100\right), 402$ (76). HRMS, $\mathrm{M}^{+}$Calcd for $\mathrm{C}_{28} \mathrm{H}_{17} \mathrm{NO}_{2} \mathrm{~S}_{2}$ : 463.0701; found: 463.0701 .

4.1.3.2. Methyl 1-(dibenzofur-4-yl)-3H-benzofuro[2,3-e]indole2-carboxylate (BFIN). Compound $2(110 \mathrm{mg}, 0.206 \mathrm{mmol})$ in DMF ( $3 \mathrm{~mL}$ ) by following the general procedure gave BFIN as a brownish solid, which was washed with ether giving a beige solid $(69.0 \mathrm{mg}, 78 \%), \mathrm{mp}>300{ }^{\circ} \mathrm{C} .{ }^{1} \mathrm{H}$ NMR $(300 \mathrm{MHz}$, $\left.\mathrm{CDCl}_{3}\right): \delta=3.66(3 \mathrm{H}, \mathrm{s}, \mathrm{OMe}), 7.27-7.42(6 \mathrm{H}, \mathrm{m}, \mathrm{ArH}), 7.50$ $(1 \mathrm{H}, \mathrm{d}, J=8.7 \mathrm{~Hz}, \mathrm{ArH}), 7.56(1 \mathrm{H}$, apparent $\mathrm{t}, J=7.5 \mathrm{~Hz}$, ArH), $7.84(1 \mathrm{H}, \mathrm{dd}, J=7.5$ and $1.2 \mathrm{~Hz}, \mathrm{ArH}), 7.90-7.94(1 \mathrm{H}$, $\mathrm{m}, \operatorname{ArH}), 7.96(1 \mathrm{H}, \mathrm{d}, J=8.7 \mathrm{~Hz}, \operatorname{ArH}), 8.04-8.07(1 \mathrm{H}, \mathrm{m}$, $\operatorname{ArH}), 8.10(1 \mathrm{H}, \mathrm{dd}, J=7.5$ and $1.2 \mathrm{~Hz}, \operatorname{ArH}), 9.45(1 \mathrm{H}, \mathrm{br} \mathrm{s}$, $\mathrm{NH}) \mathrm{ppm} .{ }^{1} \mathrm{H}$ NMR $\left(300 \mathrm{MHz}, \mathrm{DMSO}-d_{6}\right): \delta=3.62(3 \mathrm{H}, \mathrm{s}$, OMe), 7.26-7.52 $(6 \mathrm{H}, \mathrm{m}, \mathrm{ArH}), 7.53(1 \mathrm{H}$, apparent $\mathrm{t}, J=$ $7.5 \mathrm{~Hz}, \mathrm{ArH}), 7.61(1 \mathrm{H}, \mathrm{d}, J=8.7 \mathrm{~Hz}, \mathrm{ArH}), 7.77(1 \mathrm{H}, \mathrm{dd}, J=$ 7.5 and $1.2 \mathrm{~Hz}, \mathrm{ArH}), 8.05-8.08(2 \mathrm{H}, \mathrm{m}, \mathrm{ArH}), 8.20-8.24(2 \mathrm{H}$, $\mathrm{m}, \mathrm{ArH}), 12.73(1 \mathrm{H}, \mathrm{br} \mathrm{s}, \mathrm{NH}) \mathrm{ppm} .{ }^{13} \mathrm{C}$ NMR $(75.4 \mathrm{MHz}$, DMSO- $\left.d_{6}\right): \delta=51.69\left(\mathrm{OCH}_{3}\right), 109.04(\mathrm{CH}), 111.24(\mathrm{CH})$, $111.45(\mathrm{CH}), 113.62(\mathrm{C}), 113.95(\mathrm{C}), 115.51(\mathrm{C}), 117.98$ $(\mathrm{CH}), 118.73(\mathrm{C}), 119.83(\mathrm{CH}), 120.37(\mathrm{CH}), 121.16(\mathrm{CH})$, $122.56(\mathrm{CH}), 122.98(\mathrm{CH}), 123.06(\mathrm{CH}), 123.28(\mathrm{C}), 123.89$ $(\mathrm{C}), 124.19(\mathrm{C}), 124.42(\mathrm{C}), 125.31(\mathrm{CH}), 127.41(\mathrm{CH})$, $129.87(\mathrm{CH}), 137.09(\mathrm{C}), 149.47(\mathrm{C}), 154.16(\mathrm{C}), 154.58(\mathrm{C})$, $155.43(\mathrm{C}), 161.27(\mathrm{C}=\mathrm{O}) \mathrm{ppm}$. MS (EI): $\mathrm{m} / \mathrm{z}(\%) 432$ $\left(\mathrm{M}^{+}+1,11\right), 431\left(\mathrm{M}^{+}, 39\right), 399\left(\mathrm{M}^{+}-\mathrm{OMe}, 100\right), 370$ (45). HRMS, $\mathrm{M}^{+}$Calcd for $\mathrm{C}_{28} \mathrm{H}_{17} \mathrm{NO}_{4}$ : 431.1158 ; found: 431.1156 .

\subsection{Spectroscopic measurements}

Absorption spectra were recorded in a Shimadzu UV-3101PC UV-vis-NIR spectrophotometer. Fluorescence measurements were performed using a Fluorolog 3 spectrofluorimeter, equipped with double monochromators in both excitation and emission. For fluorescence quantum yield determination, the solutions were previously bubbled for 20 min with ultrapure nitrogen. Fluorescence spectra were corrected for the instrumental response of the system. The fluorescence quantum yields $\left(\Phi_{\mathrm{s}}\right)$ were determined using the standard method (Eq. 7). ${ }^{28}$ 9,10-Diphenylanthracene in ethanol was used as reference, $\Phi_{\mathrm{r}}=0.95 .^{29}$

$\Phi_{\mathrm{s}}=\left[\left(A_{\mathrm{r}} F_{\mathrm{s}} n_{\mathrm{s}}^{2}\right) /\left(A_{\mathrm{s}} F_{\mathrm{r}} n_{\mathrm{r}}^{2}\right)\right] \Phi_{\mathrm{r}}$

where $A$ is the absorbance at the excitation wavelength, $F$ is the integrated emission area and $n$ is the refraction index of the solvents used. Subscripts refer to the reference (r) or sample (s) compound.

All solutions were prepared using spectroscopic grade solvents and Milli-Q grade water.

Natural double-stranded salmon sperm DNA was obtained from Invitrogen. Salmon sperm DNA and BTIN and BFIN stock solutions were prepared in $10 \mathrm{mM}$ Tris- $\mathrm{HCl}$ buffer $(\mathrm{pH}=7.4)$ with $1 \mathrm{mM}$ EDTA. The purity of DNA was checked by monitoring the absorption spectrum and the ratio of the absorbance at 260 and $280 \mathrm{~nm}, A_{260} / A_{280}=1.95$ (good-quality DNA has an $A_{260} / A_{280}$ ratio higher than 1.8). ${ }^{39}$ The DNA concentration in number of bases (or phosphate groups) was determined from the molar extinction coefficient, $\varepsilon=$ $6600 \mathrm{M}^{-1} \mathrm{~cm}^{-1}$ at $260 \mathrm{~nm}^{40}$ The absorption and emission spectra of several solutions with different [DNA]/[compound] ratios using the same compound concentration $\left(4.2 \times 10^{-6} \mathrm{M}\right)$ were recorded. The solutions were left $24 \mathrm{~h}$ to stabilize. The absorbance at excitation wavelengths was always less than 0.1 , in order to avoid inner filter effects. All measurements were performed at room temperature $\left(25.0 \pm 0.5^{\circ} \mathrm{C}\right)$.

Binding analysis of the experimental data was performed according to McGhee and von Hippel model (Eq. 1) to determine the intrinsic binding constants and the binding site sizes, using the DNA concentration in base pairs.

\subsection{Electrochemistry}

\subsubsection{Apparatus}

The oxidation signals of BTIN and DNA were investigated by using differential pulse voltammetry (DPV) in connection with an electrochemical analysis system, the AUTOLABPGSTAT 302 and GPES 4.9 software package (Eco Chemie, The Netherlands). The three electrodes system consisted of disposable working electrode (pencil graphite electrode, $\mathrm{PGE}$ ), an $\mathrm{Ag} / \mathrm{AgCl}$ reference electrode (Model RE-1, BAS, W. Lafayette, USA) and a platinum wire as the auxiliary electrode. The raw voltammograms were treated by using the Savitzky and Golay filter (level 2) included in the General Purpose Electrochemical Software (GPES) of Eco Chemie (The Netherlands) with moving average baseline correction using a 'peak width' of $0.01 \mathrm{~V}$.

\subsubsection{The preparation of disposable electrodes}

The renewable PGE was used in voltammetric measurements for the electrochemical detection of DNA. A Tombo pencil (Japan) was used as a holder for the graphite lead. Electrical contact with the lead was obtained by soldering a metallic wire to the metallic part. The pencil was held vertically with $14 \mathrm{~mm}$ of the lead extruded outside $(10 \mathrm{~mm}$ of which was immersed in the solution).

\subsubsection{Chemicals}

The fish sperm DNA (as lyophilized powder) was obtained from Serva Company (Germany). dsDNA stock solution $(100 \mathrm{mg} / \mathrm{L})$ was prepared with TE buffer solution $(10 \mathrm{mM}$ Tris-HCl, $1 \mathrm{mM}$ EDTA, pH 8.00) and kept frozen. More dilute solutions of dsDNA were prepared in $0.05 \mathrm{M}$ acetate 
buffer solution containing $20 \mathrm{mM} \mathrm{NaCl}$ (ABS, pH 4.80). Other chemicals were of analytical reagent grade.

The stock solutions of BTIN were prepared using DMSO.

\subsubsection{Procedure for electrochemical detection of interaction of BTIN with DNA}

Each measurement involved the immobilization of the nucleic acid/detection cycle at a fresh pretreated PGE surface. All the experiments were performed at room temperature $\left(25.0 \pm 0.5^{\circ} \mathrm{C}\right)$.

4.3.4.1. Immobilization of dsDNA onto PGE surface. PGEs were pretreated by applying $+1.40 \mathrm{~V}$ for $30 \mathrm{~s}$ in ABS without stirring; $16 \mu \mathrm{g} / \mathrm{mL}$ concentration level of dsDNA was immobilized onto the pretreated PGEs by following the dip-coating procedure for $7.5 \mathrm{~min}^{20,21}$ After immobilization of DNA onto PGEs, each PGE was then rinsed with ABS for $10 \mathrm{~s}$.

Interaction of BTIN with dsDNA modified PGE: dsDNA modified PGE was immersed into the solution of BTIN in various concentrations prepared by using ABS. BTIN was accumulated into the double helix of DNA by stirring for $5 \mathrm{~min}$ without applying any potential. Then, the electrode was rinsed with ABS for $10 \mathrm{~s}$.

\subsubsection{Voltammetric transduction}

Before and after interaction, oxidation signals of both BTIN and DNA base, adenine, were measured by using DPV in ABS by scanning from +0.10 to $+1.40 \mathrm{~V}$ at $50 \mathrm{mV}$ pulse amplitude and $50 \mathrm{mV} / \mathrm{s}$ scan rate.

Repetitive measurements were carried out by renewing the surface and repeating the above assay formats by using the electrochemical transducer.

\section{Acknowledgements}

Foundation for the Science and Technology (FCT) - Portugal and FEDER, for financial support through Centro de Química and Centro de Física of Univ. do Minho, through the Project POCI/QUI/59407/2004. A.S.A. acknowledges a post-doc. grant SFRH/BPD/24548/2005.

A.E. acknowledges the financial support from Turkish Academy of Pharmacists and Turkish Pharmacists Association (TEB) and the Turkish Academy of Sciences in the framework of the Young Scientist Award Program (for A.E., KAE/TUBAGEBIP/2001-2-8). H.K. acknowledges a scholarship for a $\mathrm{Ph} . \mathrm{D}$. from Scientific and Technical Research Council of Turkey (TUBITAK).

\section{References and notes}

1. Lyne, P. D. Drug Discovery Today 2002, 7, 1047-1055.

2. Mahadevan, S.; Palaniandavar, M. Inorg. Chim. Acta 1997, 254, 291-302.

3. Yang, X.-L.; Wang, A. H.-J. Pharmacol. Ther. 1999, 83, 181-215.

4. McGown, L. B.; Joseph, M. J.; Pitner, J. B.; Vonk, G. P.; Linn, C. P. Anal. Chem. 1995, 67, 663A-668A
5. Pang, D.; Abruna, H. D. Anal. Chem. 1998, 70, 3162-3169.

6. Fritzsche, H.; Akhebat, A.; Taillandier, E.; Rippe, K.; Jovin, T. M. Nucleic Acids Res. 1993, 21, 5085-5091.

7. Gane, P. J.; Dean, P. M. Curr. Opin. Struct. Biol. 2000, 10, 401-404.

8. Graves, D.; Velea, E. L. M. Curr. Org. Chem. 2000, 4, 915-929.

9. Dougherty, G.; Pilbrow, J. R. Int. J. Biochem. 1984, 16, 1179-1192.

10. Kumar, C. V.; Asuncion, E. H.; Barton, J. K.; Turro, N. J. J. Am. Chem. Soc. 1993, 115, 8547-8553.

11. Kumar, C. V.; Punzalan, E. H. A.; Tan, W. B. Tetrahedron 2000, 56, 7027-7040.

12. Real Oliveira, M. E. C. D.; Baptista, A. L. F.; Coutinho, P. J. G.; Castanheira, E. M. S.; Hungerford, G. Photochem. Photobiol. Sci. 2004, $3,217-225$.

13. Palecek, E.; Fojta, M. Anal. Chem. 2001, 73, 63A-83A.

14. Wang, J. Nucleic Acids Res. 2000, 28, 3011-3016.

15. Erdem, A.; Ozsoz, M. Electroanalysis 2002, 14, 965-974.

16. Erdem, A.; Papakonstantinou, P.; Murphy, H. H. Anal. Chem. 2006, 78, 6656-6659.

17. Teijeiro, C.; Perez, P.; Marin, D.; Palecek, E. Bioelectrochem. Bioenerg. 1995, 38, 77-83.

18. Wang, J.; Rivas, G.; Luo, D.; Cai, X.; Valera, F. S.; Dontha, N.; Farias, P. A. M.; Shiraishi, H. Anal. Chem. 1996, 68, 2251-2254.

19. Karadeniz, H.; Gulmez, B.; Erdem, A.; Jelen, F.; Ozsoz, M.; Palecek, E. Front. Biosci. 2006, 11, 1870-1877.

20. Karadeniz, H.; Gulmez, B.; Sahinci, F.; Erdem, A.; Kaya, G. I.; Unver, N.; Kivcak, B.; Ozsoz, M. J. Pharm. Biomed. Anal. 2003, 33, 295-302.

21. Gulmez, B.; Karadeniz, H.; Erdem, A.; Ozsoz, M. Comprehensive Analytical Chemistry: 'Electrochemical Sensor Analysis'; Alegret, S., Merkoci, A., Eds.; Elsevier: Amsterdam, 2007; Vol. 49, procedure 27, pp e195-e202.

22. Erdem, A.; Kosmider, B.; Zyner, E.; Osiecka, R.; Ochocki, J.; Ozsoz, M. J. Pharm. Biomed. Anal. 2005, 38, 645-652.

23. Oliveira Brett, A. M.; Serrano, H. P.; Macedo, A.; Raimundo, D.; Marques, M. H.; La-Scalea, M. A. Electroanalysis 1996, 8, 992-995.

24. Oliveira Brett, A. M.; Macedo, T. R. A.; Raimundo, D.; Marques, M. H.; Serrano, S. H. P. Biosens. Bioelectron. 1998, 13, 861-867.

25. Fojta, M.; Havran, L.; Fulneckova, J.; Kubicarova, T. Electroanalysis 2000, 12, 926-934.

26. (a) Abreu, A. S.; Silva, N. O.; Ferreira, P. M. T.; Queiroz, M.-J. R. P. Tetrahedron Lett. 2003, 44, 3377-3379; (b) Abreu, A. S.; Silva, N. O.; Ferreira, P. M. T.; Queiroz, M.-J. R. P.; Venanzi, M. Eur. J. Org. Chem. 2003, 4792-4796; (c) Queiroz, M.-J. R. P.; Abreu, A. S.; Castanheira, E. M. S.; Ferreira, P. M. T. Tetrahedron 2007, 63, 2215-2222.

27. Abreu, A. S.; Ferreira, P. M. T.; Queiroz, M.-J. R. P.; Ferreira, I. C. F. R.; Calhelha, R. C.; Estevinho, L. M. Eur. J. Org. Chem. 2005, 2951-2957.

28. (a) Demas, J. N.; Crosby, G. A. J. Phys. Chem. 1971, 75, 991-1024; (b) Fery-Forgues, S.; Lavabre, D. J. Chem. Educ. 1999, 76, 1260-1264.

29. Morris, J. V.; Mahaney, M. A.; Huber, J. R. J. Phys. Chem. 1976, 80, 969-974.

30. Creed, D. Photochem. Photobiol. 1984, 39, 537-562.

31. Albinsson, B.; Kubista, M.; Nordén, B.; Thulstrup, E. W. J. Phys. Chem. 1989, 93, 6646-6654.

32. Lippert, H.; Ritze, H.-H.; Hertel, I. V.; Radloff, W. Chem. Phys. Lett. 2004, 398, 526-531.

33. Tatischeff, I.; Klein, R. Photochem. Photobiol. 1975, 22, 221-229.

34. Turro, N. J. Modern Molecular Photochemistry; Benjamin/Cummings: Menlo Park, California, 1978.

35. Lakowicz, J. R. Principles of Fluorescence Spectroscopy; Plenum: New York, NY, 1983.

36. Valeur, B. Molecular Fluorescence: Principles and Applications; WileyVCH: Weinheim, 2002.

37. McGhee, J. D.; von Hippel, P. H. J. Mol. Biol. 1974, 86, 469-489.

38. Leher, S. S. Biochemistry 1971, 10, 3254-3263.

39. Cao, Y.; He, X.-w. Spectrochim. Acta, Part A 1998, 54, 883-892.

40. Renault, E.; Fontaine-Aupart, M. P.; Tfibel, F.; Gardes-Albert, M.; Bisagni, E. J. Photochem. Photobiol. B: Biol. 1997, 40, 218-227. 